\title{
EXTERNAL ANTECEDENTS OF ENTREPRENEURIAL ORIENTATION IN JUNIOR HIGH SCHOOL STUDENTS
}

\author{
Ersa Lanang Sanjaya*)1, Jimmy Ellya Kurniawan*), Stefani Virlia*) \\ ${ }^{*}$ School of Psychology, Universitas Ciputra Surabaya \\ Jl. Citraland CBD Boulevard, Surabaya 60219, Indonesia
}

\begin{abstract}
Several previous studies on entrepreneurial orientation are studied were examined in the bussiness context and show the contribution of internal factors within individuals to the development of entrepreneurial orientation. However, only a few research that focused on entrepreneurship orientation in the context of education, especially for junior high school students in Java Island. This study aims to examine external factors, about authoritative parenting, and creativity climate for the entrepreneurial orientation of junior high school students. The research respondents were 291 junior high school adolescents in Jakarta, Tangerang, Bandung, Yogyakarta, Semarang and Surabaya. Data collection was carried out from August to November 2019. The data were analyzed using multiple regressions. The results showed that there was a significant influence between the authoritative parenting and the creativity climate on entrepreneurial orientation. The role of parents in providing responsible freedom to children allows children to be more courageous in facing risks, innovative, and open to competitive situations. The creative climate at school allows students to express their ideas and get used to solving problems.
\end{abstract}

Keywords: entrepreneurial orientation, authoritative parenting, creativity climate, adolescents, Indonesia

Abstrak: Penelitian terkait orientasi kewirausahaan seringkali dikaji dalam konteks bisnis dan secara konsisten menunjukkan kontribusi faktor internal dalam diri individu terhadap pengembangan orientasi kewirausahaan. Permasalahannya, belum banyak penelitian tentang orientasi kewirausahaan dilakukan dalam konteks pendidikan, khususnya bagi siswa SMP di Pulau Jawa. Penelitian ini bertujuan untuk menguji faktor eksternal yaitu pola asuh otoritatif dan iklim kreativitas terhadap orientasi kewirausahaan siswa SMP. Responden penelitian kali ini adalah 291 remaja SMP di Jakarta, Tangerang, Bandung, Yogyakarta, Semarang dan Surabaya. Pengambilan data dilakukan mulai dari AgustusNovember 2019. Data dianalisis menggunakan regresi berganda. Hasil penelitian menunjukkan bahwa terdapat pengaruh yang signifikan antara pola asuh otoritatif dan iklim kreativitas terhadap orientasi kewirausahaan. Peran orang tua dalam memberikan kebebasan yang bertanggung jawab kepada anak memungkinkan anak lebih berani dalam menghadapi risiko, inovatif, dan siap menghadapi persaingan. Iklim kreatif di sekolah membuat siswa bisa mengekspresikan idenya dan terbiasa untuk menyelesaikan masalah.

Kata kunci: orientasi kewirausahaan, pengasuhan otoritatif, iklim kreatif, remaja, Indonesia

${ }^{1}$ Corresponding author:

Email: ersa.sanjaya@ciputra.ac.id 


\section{INTRODUCTION}

Today, it is increasingly acknowledged that entrepreneurship is an important aspect of a country's economic and social development (Park, 2017). Entrepreneurship is formed through intentional and planned behavior (Krueger et al. 2000). Hisrich et al. (2013) argue that one of the strongest predictors of entrepreneurship is entrepreneurial intention. Koe (2016) through his research revealed that entrepreneurial intention is formed by entrepreneurial orientation. Entrepreneurial orientation is, therefore, important for the continual development of entrepreneurship.

Entrepreneurial orientation is ideally developed during adolescence through education in compulsory schooling (Santana et al. 2016). Peterman and Kennedy (2003) states that the early initiation of adolescents into entrepreneurship helps them to determine and prepare for future careers as entrepreneurs. Research into entrepreneurial orientation is still largely focused on the context of adults and businesses, for example entrepreneurial orientation in the context of business performance (Omar et al. 2016; Arshad et al. 2014; Davis et al. 2011), family businesses (Charupongsopon and Puriwat, 2017), small and medium enterprises (Zeebaree and Siron, 2017), and low-income households (Kumar et al. 2018). Unfortunately, there has been little research on entrepreneurial orientation in the context of adolescents and education, meaning entrepreneurial orientation in adolescents still needs to be investigated. In addition, more specifically, the antecedents of entrepreneurial orientation are generally examined in relation to internal factors, such as personality, motivation (Pittino et al. 2017), thinking style (Groves, 2008), and opportunity recognition (Santos et al. 2017). It is therefore necessary to study the external factors that influence the antecedents of entrepreneurial orientation.

The concept and measurement of entrepreneurial orientation were initially aimed at the organizational and company level. Miller and Friesen (1982) first measured entrepreneurial orientation in companies related to continuous innovation and risk taking. Miller (1983) refined the previous research by looking at entrepreneurial orientation in companies in terms of the dimensions of innovation, risk taking, and proactiveness to beat competitors. Lumpkin and Dess (1996) also measured entrepreneurial orientation at the organizational level using 5 dimensions:autonomy, innovativeness, risk taking, proactiveness and competitive aggressiveness. Entrepreneurial orientation at the individual level has also been measured in company executives (Covin and Slevin, 1988), business owners (Bolton,2012), and students (Bolton and Lane, 2012). In relation to the adolescent context, Kurniawan et al. (2019) specifically investigated entrepreneurial orientation at the high school level and compiled 3 dimensions relevant to high school students: innovativeness, risky proactiveness, and competitiveness.

Early adolescence is a period in which a person goes through many transitions. From a biological aspect, this transition is characterized by experiencing puberty, from a social aspect by entering junior high school, and from a cognitive aspect by experiencing an increase in cognitive ability, allowing early adolescents to think abstractly, idealistically, and logically (Eccles, 1999; Santrock, 2007). Early adolescents are in a phase of identity crisis, in which their search for identity can be attained through self-exploration (Steinberg and Morris, 2001). During this time, parents can take a role by intentionally creating opportunities for adolescents in order that they can experience various types of roles that can later become capital as they grow older (Panahi, 2015). Therefore, the role of parents, which manifests in the form of parenting style, is key for adolescents in developing their identity (Santrock, 2007), self-esteem (Eccles, 1999) beliefs, expectations, and career plan (Boz and Ergeneli, 2014).

Parents with authoritative parenting styles encourage their children to be independent while still limiting and controlling their actions. Parents do not always have to be controlling, but provide their children with more open opportunities to explore in order that their children can make their own decisions based on their own considerations (Niaraki and Rahimi, 2013). Authoritative parenting styles can also consistently be associated with positive development outcomes in adolescents, for example psychosocial competencies such as maturity, resilience, optimism, independence, social competence, self-esteem, and achievement in children (Kuppens and Ceulemans, 2018). Authoritative parenting styles support the development of leadership, self-confidence, autonomy, perseverance and independence in adolescents, where these values lead toward entrepreneurial orientation (SchmittRodermund, 2004). 
In addition to family, school is also a sensitive aspect in the development of early adolescents in junior high school (Eccles, 1999). The form of entrepreneurship education carried out by educational institutions affects the mindset and entrepreneurial behavior of students (Irawanto and Noviati, 2021) Specifically, Ibrahim and Lucky (2014) argue that environment is a key factor in the development of entrepreneurship. Early adolescents need to be equipped with basic skills and knowledge, such as creative problem solving, searching for and critiquing information, and communicating effectively (Unicef, 2011).

A creative school climate increases student engagement (Bahia, Vega, and Galvao, 2014) by facilitating freedom, challenges, support for ideas, conflicts to be solved, knowledge exchange and sharing, selfconfidence, openness, time to study, time to play and risk taking (Isaksen et al. 2003). The connection is that entrepreneurship is always related to understanding problems within the community, and confidence to develop ideas and find the most effective solutions when implementing them, where these factors are closely related to learning methods that emphasize a creative climate (Hamidi et al. 2008). According to Bahia et al. (2014), there are five dimensions of a creative climate in school, including support for the expression of ideas, students' perceptions of creativity, desire for knowledge, autonomy, and stimulation to produce ideas where these values are aligned with entrepreneurship orientation.

Research related to entrepreneurial orientation is dominated by studies of internal factors, therefore this study seeks to examine external factors as predictors of entrepreneurial orientation. The predictor chosen is authoritative parenting that allows students to be creative and more independent. In addition, the school's creative climate factor also predicts innovative thinking patterns in students where innovation is included in the entrepreneurial orientation dimension. The purpose of the research is to se the role of authoritative parenting style and creative climate toward entrepreneurial orientation.

\section{METHODS}

This study takes a quantitative approach using the survey method to collect data. Data collection was carried out from August to November 2019 through an online survey. Before data collection is carried out, communication is carried out with school headmaster to ask for permission. The subjects of this study consist of 291 junior high school students in grades 7 and 8 from six large cities in Java, including Jakarta, Tangerang, Bandung, Yogyakarta, Semarang, and Surabaya. We use quota random sampling to determine the number of respondents in each junior high school in each city. The hyphothesis is authoritative parenting style and creative climate will positively associate with entrepreneurial orientation.

The data were collected using three types of scales: for the dependent variable (Table 1) use the entrepreneurial orientation scale, for independent variable (Table 2) use the creative climate in schools scale, and the democratic parenting scale. The entrepreneurial orientation scale consists of 7 items for the dimension of innovativeness with CITC $0.402-0.651$ and $\alpha=0.791 ; 9$ items for the dimension of risky proactiveness with CITC 0.562 0.659 and $\alpha=0.871$; and 8 items for the dimension of competitiveness with CITC $0.414-0.681$ and $\alpha=0.823$ (Kurniawan, et al, 2019; Kurniawan, et al, 2021). The authoritative parenting scale uses the parenting styles and dimensions questionnaire short version (PSDQShort version), which is a modification of the original PSDQ scale (Robinson et al. 1995). The PSDQ scale consists of 5 items for the dimension of connection (warmth and involvement) with CITC 0.421-0.748 and $\alpha=0.804 ; 5$ items for the dimension of regulation (reasoning/induction) with CITC $0.398-0.832$ and $\alpha$ $=0.852$; and 5 items for the dimension of autonomy (democratic participation) with CITC 0.326-0.709 and $\alpha=0.795$. The creative climate in schools scale uses the creative climate scale from Bahia, Veiga, dan Galvao (2014) The creative climate in schools scale consist of 5 item determined that CITC 0.431-0.731 and $\alpha=0.806$.

\section{RESULTS}

The assumption tests were conducted before the multiple regression tests. The results of the normality test using Kolmogorov-Smirnov show that the significance of the entrepreneurial orientation variable is 0.200 . It can therefore be concluded that the data are normally distributed. The linearity tests for creative climate and entrepreneurial orientation, and authoritative parenting style and entrepreneurial orientation had a significant value of 0.000 , and can therefore be classified as 
linear. The heteroscedasticity test using the Glejser test produced significant values for creative climate and authoritative parenting of $>0.05$, meaning the two variables do not show indications of heteroscedasticity, but rather homoscedasticity. Meanwhile, the VIF value for the variables of creative climate and authoritative parenting is 1.37 , which is smaller than 10 , and the tolerance value is $73 \%$, which is greater than $10 \%$, meaning there is no multicollinearity. Based on the results of the assumption tests conducted, it can be concluded that all assumption tests were fulfilled and, therefore, multiple regression tests could be conducted.

Based on the results of the statistical calculations using multiple regressions, it was found that the creative climate variable and the authoritative parenting variable had an effect on entrepreneurial orientation. Based on Table 3, the creative climate and authoritative parenting variables had an $18.7 \%$ effect on entrepreneurial orientation. Based on Table 4, The regression equation that can be used to predict entrepreneurial orientation in junior high school students based on external factors is:

\section{Entrepreneurship Orientation $=46.942+0.731$ Creative Climate $+\mathbf{0 . 3 8 2}$ Authoritative Parenting}

This study found that external factors influence the development of entrepreneurial orientation during adolescence. Vygotsky's sociocultural theory states that human mental processes are formed through social interactions (Shabani, 2016). Social interactions are the foundation for human learning and development for the construction of knowledge (Lantolf, 2004). Learning is the process of internalizing ability and knowledge from social factors to one's cognitive level (Walqui, 2006). It is interesting to note that the formation of cognitive schemes, knowledge, or skills can only occur through social interactions with clear objectives, such as problem solving. The emphasis of Vygotsky's sociocultural theory is the interaction of each individual's function to form a new cognitive system (Shabani, 2016). In this study, the function of parents and the function of the school play a role in children's development, particularly in relation to entrepreneurial orientation.

\section{Impact of Authoritative Parenting to Entrepreneurial Orientation}

The authoritative parenting style is a style of parenting that combines warmth and involvement with set rules and consistent consequences (Simons and Conger, 2007). In the authoritative parenting style, parents exercise control over their children, but not restraint (Aunola et al. 2000). More specifically, the authoritative parenting style is related to how parents actively participate in the lives of their children, openly communicate, trust, accept, and support the psychological autonomy of their children, and monitor their children's whereabouts (Aunola et al. 2000). Sahithya et al. (2019), based on the results of their literature review, state that children who are raised in families with authoritative parenting have a higher level of self-efficacy, internal locus of control, and better academic achievement. In addition, Amandep (2017) also states that children who are raised with authoritative parenting have higher self-esteem, self-concept, and self-awareness compared to children raised with different parenting styles.

Table 1. Dependent variable

\begin{tabular}{|c|c|c|c|c|c|}
\hline Dependent variable & Dimension & $\begin{array}{l}\text { Number } \\
\text { of Items }\end{array}$ & $\begin{array}{c}\text { Cronbach } \\
\text { Alpha }\end{array}$ & $\begin{array}{l}\text { Corrected Item- } \\
\text { Total Correlation }\end{array}$ & Loading Factor \\
\hline \multirow{3}{*}{$\begin{array}{l}\text { Entrepreneurial Orientation } \\
\text { (Dependent Variable) }\end{array}$} & Innovativeness & 7 & 0.791 & $0.402-0.651$ & $0.583-0.740$ \\
\hline & Risky Proactiveness & 9 & 0.871 & $0.562-0.659$ & $0.515-0.736$ \\
\hline & Competitiveness & 8 & 0.823 & $0.414-0.681$ & $0.538-0.796$ \\
\hline
\end{tabular}

Table 2. Independent variable

\begin{tabular}{llcccc}
\hline \multicolumn{1}{c}{ Independent variable } & \multicolumn{1}{c}{ Dimension } & $\begin{array}{c}\text { Number } \\
\text { of Items }\end{array}$ & $\begin{array}{c}\text { Cronbach } \\
\text { Alpha }\end{array}$ & $\begin{array}{c}\text { Corrected Item- } \\
\text { Total Correlation }\end{array}$ & $\begin{array}{c}\text { Loading Factor } \\
\text { Authoritative Parenting }\end{array}$ \\
Style & Connection & 5 & 0.804 & $0.421-0.748$ & $0.711-0.869$ \\
& Regulation & 5 & 0.852 & $0.398-0.832$ & $0.761-0.859$ \\
Creative Climate & Autonomy & 5 & 0.795 & $0.326-0.709$ & $0.699-0.843$ \\
& Unidimension & 5 & 0.806 & $0.431-0.731$ & $0.683-0.818$ \\
\hline
\end{tabular}


Table 3. Correlation coefficient

\begin{tabular}{cccc}
\hline $\mathrm{R}$ & $\mathrm{R}$ Square & Adjusted R Square & Std. Error of the Estimate \\
\hline .432 & .187 & .181 & 11.96445 \\
\hline
\end{tabular}

Table 4. Multiple reggresion

\begin{tabular}{|c|c|c|c|c|c|}
\hline \multirow[t]{2}{*}{ Model } & \multicolumn{2}{|c|}{ Unstandardized Coefficients } & \multirow{2}{*}{$\frac{\text { Standardized Coefficients }}{\text { Beta }}$} & \multirow[t]{2}{*}{$\mathrm{t}$} & \multirow[t]{2}{*}{ Sig } \\
\hline & $\mathrm{B}$ & Std. Error & & & \\
\hline Constant & 46.942 & 4.296 & & 10.926 & .000 \\
\hline Creative Climate & .731 & .227 & .200 & 3.216 & .001 \\
\hline Authoritative Parenting Style & .382 & .081 & .293 & 4.706 & .000 \\
\hline
\end{tabular}

The main point of authoritative parenting is that parents support their children's autonomy to act and think (Sahithya et al. 2019). The parents still place expectations on their children, but it is important that these expectations are always accompanied with efforts to explain to the children the reasons behind these expectations. In addition, parental assistance in meeting these expectations is also important for children (Zurcher et al. 2018). For the context of adolescents, the dimension of proactiveness in the entrepreneurial orientation variable was modified to risky proactiveness. This is because proactiveness, in the context of adolescents, is inherently risky because during this phase adolescents feel a need to be accepted by their peer group or their friends (Kurniawan et al. 2019). When adolescents are raised with authoritative parenting, they possess an internal locus of control, meaning their behavior is determined by their own initiatives rather than peer influence. In addition, Mehrinejad, Rajabimoghadam, and Tarsafi (2015) argue that when children and adolescents are given the opportunity to satisfy their feelings of curiosity, they tend to enjoy these feelings and attempt to satiate them, which manifests in proactive and innovative behavior. Parents with authoritative parenting styles also always support their children in achieving targets that have been discussed together, impacting their academic achievement (Paler et al. 2019). Andre (2013) states that the desire to achieve is what makes a person competitive, where competitiveness is one of the dimensions of entrepreneurial orientation.

\section{Impact of Creative Climate to Entrepreneurial Orientation}

Veijan, Kamarudin, and Kadir, (2016) explain that the school climate is a social system intentionally designed for the purpose of learning. Within this system are characteristics and qualities that are expressed through goals, leadership, the establishment of norms, interpersonal relationships, values, and organizational structures (National School Climate Council, 2007). The school climate, which is built on these unique characteristics, is passed down to students in the form of teaching, influencing the moods, motivation, creativity, and productivity of both teachers and students either positively or negatively. As a result, the school climate impacts the formation of students' personalities, their academic success, and the organizational efficiency of the school (Veijan et al. 2016).

Mohsin and Yunos (2008) state that a creative climate in schools is evident in things such as learning being fun for students, students feeling valued, loved and respected, students taking an active role in class, students feeling proud of and feeling part of their school, teachers functioning as mentors as well as sources of knowledge for students, students being free to discuss their problems, teaching strategies that prioritize teamwork, and learning experiences that relate to the everyday lives of students. Ekvall (1996) also argues that the development of a creative school climate is related to students' psychological processes within the school, such as challenges, freedom, support for new ideas, trust and openness, games and humor, debates, risk taking, and opportunities to develop new ideas and present them. As a result, when students are in a school that emphasized a creative climate, they are given the opportunity to continuously innovate, to become accustomed to being proactive in developing ideas and to compete with their ideas in a healthy manner, meaning that students in creative school environments, therefore, have high levels of entrepreneurial orientation. 


\section{Managerial Implications}

The results of this study provide an overview related to external factors that have an influence on entrepreneurship orientation. The managerial implication from this study, both parents and education institution need to understand the importance of cooperation between parents and schools to develop entrepreneurship from adolescents. It is necessary to design programs that involve families, schools, and students together.Parents must understand that parenting styles can influence the entrepreneurial orientation of students. Based on the results of the study, the parenting pattern that can increase the entrepreneurial orientation of junior high school students is authoritative parenting where this parenting pattern emphasizes connection, regulation, and autonomy. As well as schools must continue to develop themselves by creating a creative learning atmosphere The creative climate in the school emphasizes the implementation of activities that are oriented towards challenges and problem solving. In addition, schools can be a place for students to stimulate and express ideas, share knowledge, and calculate risks.

\section{CONCLUSIONS AND RECOMMENDATIONS}

\section{Conclusions}

Authoritative parenting style and creative climate at school are external antecedent that have an influence on entrepreneurial orientation in junior high school adolescents. Things that must be considered, even though someone is already in adolescents' stages, parenting factor is still an important part of developing the entrepreneurial orientation of adolescents. In addition, the readiness of schools to provide creative education also affects the entrepreneurial orientation of adolescents. The limitation of this research is the way of collecting data which is cross-sectional.

\section{Recommendations}

Research related to entrepreneurship in the context of students needs to be improved. For further research, it will be better if it is done using a longitudinal approach so that the relationship between variables or interventions can be seen as causality. Future research can also include other variables such as combining external factors and internal factors including demographic factors of students so that a more comprehensive model of entrepreneurial orientation can be formed in junior high school students.

\section{ACKNOWLEDGEMENTS}

We acknowledge the support and generosity of Kemenristek Dikti Republic of Indonesia as well as Penelitian Terapan Unggulan Perguruan Tinggi (PTUPT) for this research.

\section{REFERENCES}

Amandep. 2017. Emotional intelligence in relation to perceived parenting style of early adoles cents. The International Journal of Indian Psychology 4(3):173-182. https://doi. org/10.25215/0403.020

André R. 2013. An examination of the competitive attitudes of entrepreneurs:Implications for entrepreneurial orientation at the individual level. Journal of Developmental Entrepreneurship 18(2): 1-23. https://doi.org/10.1142/ S1084946713500088

Arshad AS et al. 2014. The impact of entrepreneurial orientation on business performance:a study of technology-based smes in Malaysia. Procedia Social and Behavioral Sciences 130(1996): 4653. https://doi.org/10.1016/j.sbspro.2014.04.006

Aunola K, Stattin H, Nurmi JE. 2000. Parenting styles and adolescents' achievement strategies. Journal of Adolescence 23(2): 205-222. https://doi. org/10.1006/jado.2000.0308

Bahia S, Veiga F, Galvão D. 2014. Creative climate and engagement of students in school:How do they relate? In F. Veiga (ed): Envolvimento dos Alunos na Escola:Perspetivas Internacionais da Psicologia e Educação/Students 'Engagement in School:International Perspectives of Psychology and Education, Lisboa:Instituto de Educação da Universidade de Lisboa.

Bolton DL, Lane MD. 2012. Individual entrepreneurial orientation:development of a measurement instrument.Education + Training 54(2):219-233. https://doi.org/10.1108/00400911211210314

Bolton DL. 2012. Individual Entrepreneurial orientation:Further Investigation of a Measurement Instrument. Academy of Entrepreneurship Journal 18:91-98. 
Boz A, Ergeneli A. 2014. Women entrepreneurs' personality characteristics and parents' parenting style profile in Turkey. Procedia - Social and Behavioral Sciences 109:92-97. https://doi. org/10.1016/j.sbspro.2013.12.425

Charupongsopon W, Puriwat W. 2017. The influence of entrepreneurial orientation and family business's resources and capabilities on marketing performances. European Research Studies Journal 20(2): 150-163.

Covin G, Slevin D, and P. (1988). The influence of organization structure on the utility of an entrepreneurial top management style . Journal of Management Studies 25(3): 321-334.

Davis JL et al.2011. Entrepreneurial orientation and firm performance:The moderating role of managerial power. American Journal of Business 25(2): 4154. https://doi.org/10.1108/19355181201000009

Eccles JS. 1999. The development of children ages 6 to 14. Future of Children 9(2): 30-44. https://doi. org/10.2307/1602703

Ekvall G. 1996. Organizational climate for creativity and innovation. Journal of Work and Organizational Psychology 5:105-123.

Groves K. 2008. Examining the antecedents and outcomes of Romanian entrepreneurial orientation. Management and Marketing 3(3): $3-18$.

Hamidi DY, Wennberg K, Berglund H. 2008. Creativity in entrepreneurship education. Journal of Small Business and Enterprise Development 15(2): 304-320. https://doi. org/10.1108/14626000810871691

Hisrich RD, Kearney C. 2013. Managing innovation and entrepreneurship. Sage Publications.

Ibrahim NA, Lucky EO. 2014. Relationship between entrepreneurial orientation, entrepreneurial skills, environmental factor and entrepreneurial intention among Nigerian students in UUM. Entrepreneurship and Innovation Management Journal 2(4): 203-213

Irawanto DW, Novianti KR. 2021. Entrepreneurship education in higher education:optimizing innovative behaviour of $\mathrm{z}$ generation. Indonesian Journal of Business and Entrepreneurship 7(1): 11-17. https://doi.org/10.17358/ijbe.7.1.11

Isaksen SG, Lauer KJ, Wilson GV. 2003.An examination of the relationship between personality type and cognitive style. Creativity Research Journal, 15(04): 343-354.

Koe WL. 2016. The relationship between Individual
Entrepreneurial Orientation (IEO) and entrepreneurial intention. Journal of Global Entrepreneurship Research 6 (13): 1-11 https:// doi.org/10.1186/s40497-016-0057-8

Krueger NF, Reilly MD, Carsrud AL. 2000. Competing models of entrepreneurial intentions. Journal of Business Venturing 15(5): 411-432. https://doi. org/10.1016/S0883-9026(98)00033-0

Kurniawan JE et al. 2019. Developing a measurement instrument for high school students' entrepreneurial orientation. Cogent Education 6(1): 1-12. https://doi.org/10.1080/2331186x.2 018.1564423

Kurniawan JE, Sanjaya EL, Virlia S. 2021. Confirmatory factor analysis and norming of the high school student's entrepreneurial orientation scale. Psychology and Education Journal 58(2): 1726. https://doi.org/10.17762/pae.v58i2.1052

Kumar $\mathrm{N}$ et al. 2018. Entrepreneurial orientation and antecedents of low-income household heads in Kelantan, Malaysia. Journal of International Studies 11(1): 140-151. https:// doi.org/10.14254/2071-8330.2018/11-1/10

Kuppens S, Ceulemans E. 2019. Parenting styles:a closer look at a well-known concept. Journal of Child and Family Studies 28(1): 168-181. https://doi.org/10.1007/s10826-018-1242-x

Lantolf JP. 2004. Overview of sociocultural theory. In O. S. John, K. van Esch, and E. Schalkwijk (Eds.): New insights in second language learning and teaching. Frankfurt:Peter Lang Verlag.

Lumpkin GT, Dess GG. 1996. The entrepreneurial clarifying it construct and linking orientation. Academy of Management Review 21(1): 135172. https://doi.org/10.2307/258632

Mehrinejad SA, Rajabimoghadam S, Tarsafi M. 2015. The relationship between parenting styles and creativity and the predictability of creativity by parenting styles. Procedia - Social and Behavioral Sciences 205(May): 56-60. https:// doi.org/10.1016/j.sbspro.2015.09.014

Miller D, Friesen PH. 1982. Innovation in conservative and entrepreneurial firms:Two models of strategic momentum. Strategic Management Journal 3:1-25.

Miller D. 1983. The correlates of entrepreneurship in three types of firms. Management Science 29(7): 770-791. https://doi.org/10.1287/mnsc.29.7.770

Mohsin M, Yunos N. 2008. Peranan guru dalam memupuk kreativiti pelajar. Journal Pengajian Umum 9:57-72. 
National School Climate Council. 2007. The School Climate Challenge:Narrowing the gap between school climate research and school climate policy, practice guidelines and teacher education policy. Available at:http://www.schoolclimate. org/climate/documents/policy/school-climatechallenge-web.pdf

Niaraki FR, Rahimi H. 2013. The impact of authoriative, permissive, and authortaian behavior of parents on self-consept, psychological health and life quality. Scholarly Journals 2:78-85.

Omar NA, Aris HM, Nazri MA. 2016. The effect of entrepreneurial orientation, innovation capability and knowledge creation on firm performance:A perspective on small scale entrepreneurs. Jurnal Pengurusan 48:187-200.

Paler JN et al. 2019. Parenting style and task performance of students. International Journal of Scientific and Research Publications (IJSRP) 9(1): p8537. https://doi.org/10.29322/ijsrp.9.01.2019.p8537

Panahi S. 2015. Impact of modernization on development of adolescents the media, culture, and technology. Unique Journal of Pharmaceutical and Biological Sciences 3(2): 15-22.

Park C. 2017. A study on effect of entrepreneurship on entrepreneurial intention. Asia Pacific Journal of Innovation and Entrepreneurship 11(2): 159170. https://doi.org/10.1108/apjie-08-2017-024

Peterman NE, Kennedy J. 2003. Influencing students' perception ofentrepreneurship. Entrepreneurship Theory and Practice 129-144.

Pittino D, Visintin F, Lauto G. 2017. A configurational analysis of the antecedents of entrepreneurial orientation. European Management Journal, 35(2): 224-237. https://doi.org/10.1016/j. emj.2016.07.00

Robinson CC et al. 1995. Authoritative, authoritarian, and permissive parenting practices:development of a new measure. Psychological Reports 77:819-830.

Santrock JW. 2007. Child development. 11th Edition, McGraw-Hill, Boston.

Santana Veg LE, González-Morales O, Feliciano García L. 2016. Entrepeneurship and adolescents. Journal of New Approaches in Educational Research 5(2): 123-129.https://doi.org/10.7821/ naer.2016.7.165
Santos G, Marques CS, Ferreira JJM. 2018. What are the antecedents of women's entrepreneurial orientation? International Entrepreneurship and Management Journal 14(4): 807-821. https:// doi.org/10.1007/s11365-017-0481-4

Sahithya BR, Manohari SM, Vijaya R. 2019. Parenting styles and its impact on children-a cross cultural review with a focus on India. Mental Health, Religion and Culture 22(4): 357-383. https:// doi.org/10.1080/13674676.2019.1594178

Schmitt-Rodermund E. 2004. Pathways to successful entrepreneurship:Parenting, personality, early entrepreneurial competence, and interests. Journal of Vocational Behavior 65(3): 498-518. https://doi.org/10.1016/j.jvb.2003.10.007

Shabani K. 2016. Applications of Vygotsky's sociocultural approach for teachers' professional development. Cogent Education 3(1): 1-10. https://doi.org/10.1080/2331186X.2016.125217 7

Simons LG, Conger RD. 2007. Linking mother-father differences in parenting to a typology of family parenting styles and adolescent outcomes. Journal of Family Issues 28(2): 212-241. https:// doi.org/10.1177/0192513X06294593

Steinberg L, MorrisAS. 2001.Adolescent Development. In Annual Reviews Psychology, 3-110.

UNICEF. 2011. Adolescence; An age of opportunity. New York:UNICEF.

Veijan G, Kamarudin N, Kadir SA. 2016. School Creative Climate:Factors Influence Fostering Creativity School. International Journal of Education and Training (InjET) 2(1): 1-5.

Walqui A. 2006. Scaffolding instruction for English language learners:A conceptual framework. International Journal of Bilingual Education and Bilingualism 9(2): 159-180. https://doi. org/10.1080/13670050608668639

Zeebaree MRY, Siron RB. 2017. International review of management and marketing the impact of entrepreneurial orientation on competitive advantage moderated by financing support in SMEs. International Review of Management and Marketing 7(1): 43-52.

Zurcher JD et al. 2018. Parenting and Cyberbullying Across Adolescence. Cyberpsychology, Behavior, and Social Networking 21(5): 294-303. https:// doi.org/10.1089/cyber.2017.0586 